\title{
Self-cleaning and leniency: comparable objectives but different levels of success?
}

Citation for published version (APA):

Schoenmaekers, S. (2018). Self-cleaning and leniency: comparable objectives but different levels of success? European Procurement \& Public Private Partnership Law Review, 13(1), 3-17. [1]. https://doi.org/10.21552/EPPPL/2018/1/4

Document status and date:

Published: 18/04/2018

DOI:

10.21552/EPPPL/2018/1/4

Document Version:

Publisher's PDF, also known as Version of record

Document license:

Taverne

Please check the document version of this publication:

- A submitted manuscript is the version of the article upon submission and before peer-review. There can be important differences between the submitted version and the official published version of record.

People interested in the research are advised to contact the author for the final version of the publication, or visit the DOI to the publisher's website.

- The final author version and the galley proof are versions of the publication after peer review.

- The final published version features the final layout of the paper including the volume, issue and page numbers.

Link to publication

\footnotetext{
General rights rights.

- You may freely distribute the URL identifying the publication in the public portal. please follow below link for the End User Agreement:

www.umlib.nl/taverne-license

Take down policy

If you believe that this document breaches copyright please contact us at:

repository@maastrichtuniversity.nl

providing details and we will investigate your claim.
}

Copyright and moral rights for the publications made accessible in the public portal are retained by the authors and/or other copyright owners and it is a condition of accessing publications that users recognise and abide by the legal requirements associated with these

- Users may download and print one copy of any publication from the public portal for the purpose of private study or research.

- You may not further distribute the material or use it for any profit-making activity or commercial gain

If the publication is distributed under the terms of Article $25 \mathrm{fa}$ of the Dutch Copyright Act, indicated by the "Taverne" license above, 


\title{
Self-Cleaning and Leniency: Comparable Objectives but Different Levels of Success?
}

\begin{abstract}
Sarah Schoenmaekers*
Leniency policies within the framework of competition law make it possible for companies involved in a bid rigging cartel to obtain either total immunity or a reduction of fines. Such policies have proven to be very successful as most cartels that have been detected in the EU were revealed by a cartel member applying voluntarily for leniency. While leniency policies in the course of competition law are also very successful in the United States, self-cleaning possibilities within the framework of public procurement law, such as voluntary disclose of wrongdoings, exist as well but have been sparingly used by firms and individuals involved in misconduct. To overcome the lack of incentive effects, the US Federal Acquisition Regulation was revised in 2008 so that firms and individuals face the risk of suspension or debarment not only for misconduct itself, but also for the failure to report such misconduct. A system of mandatory disclose of information was hence introduced. By studying the underlying rationale of leniency and self-cleaning policies and by comparing the EU and US system of self-cleaning, this articles tries to explain the level of success of leniency programmes vis-à-vis incentive-based self-cleaning policies and tries to establish whether the EU's selfcleaning policy as codified in Directive 2014/24/EU will be effective to increase integrity in public procurement.
\end{abstract}

\section{Introduction}

Article 57(6) of Directive 2014/24/EU ${ }^{1}$ allows economic operators subjected to a mandatory or discretionary exclusion ground within the framework of a public procurement procedure to provide evidence that it has taken measures which are sufficient to demonstrate its reliability despite the existence of the ground for exclusion. To this extent, economic operators can for example prove that they have paid or have undertaken to pay compensation in respect of any damage caused by their criminal offence or misconduct. Furthermore, they can demonstrate that they have clarified certain facts and circumstances in a comprehensive manner by actively collaborat-

DOI: 10.21552/epppl/2018/1/4

* Sarah Schoenmaekers, Assistant professor at Maastricht University.

1 Directive 2014/24/EU of the European Parliament and of the Council of 26 February 2014 on public procurement and repealing Directive 2004/18/EC, OJ L 94, 28.3.2014, p. 65-242.

2 Case C-21/03 Fabricom [2005] I-01559. ing with the investigating authorities or have taken concrete technical, organisational and personnel measures that are appropriate to prevent further criminal offences or misconduct. If such evidence is considered to be sufficient by the contracting authority, this authority cannot exclude the economic operator from the procurement procedure. Economic operators are free to decide whether or not to engage in self-cleaning measures for procurement purposes as the Directive does not contain any obligation to restore trustworthiness. While Directive 2014/24/EU only had to be implemented by 18 April 2016, the Court of Justice already indicated in the 2005 Fabri$\mathrm{com}^{2}$ case that operators should be given the opportunity to prove that they did not distort competition. Nevertheless, many EU contracting authorities do not have much experience with the application of the self-cleaning principle.

The United States' public procurement system is much more developed and mature than the EU system. Already in 1986, the Department of Defence set up a formal programme through which defence contractors could reduce the risk or even completely avoid debarment in the United States if they volun- 
tarily disclosed their wrongdoing. ${ }^{3}$ This programme was based on the premise that self-cleaning and selfmonitoring increased compliance and integrity in the procurement process. ${ }^{4}$ In 2006, the World Bank also set up the Voluntary Disclosure Program which allows firms and individuals to avoid debarment if they voluntarily disclose their wrongdoings through the programme. However, even though the US' and World Bank's disclosure initiatives offered economic operators the benefit of avoiding debarment, this opportunity was only sparingly seized as the programmes did not lead to a significant increase in reporting.

To overcome this situation of non-cooperation, the US government has replaced the voluntary disclosure system by a system of mandatory disclosure in 2008 for the acquisition of supplies and services by all federal executive agencies. As held by Article 3.1003(2) of the Federal Acquisition Regulation (FAR), a contractor may be suspended and/or debarred for knowing failure by a principal to timely disclose to the Government, in connection with the award, performance, or closeout of a Government contract performed by the contractor or a subcontract awarded thereunder, credible evidence of a violation of Federal criminal law involving fraud, conflict of interest, bribery, or gratuity violations. ${ }^{5}$ The suspension or debarment can take place until three years after the final payment. ${ }^{6}$ It follows that firms and individuals now face the risk of suspension or debarment not only for their misconduct as such, but also for the failure to report such misconduct. ${ }^{7}$

While the self-cleaning policy of the World Bank and the initial policy of the US did not lead to a significant increase in reporting, leniency applications in the framework of competition law have always been high in number. This article discusses the reasons for this discrepancy and aims to estimate the level of success of self-cleaning applications in the EU. As leniency applications are restricted to members of a cartel, the exclusion ground that will be focussed on is the one mentioned in Article 57(4)(d), which holds that contracting authorities holding sufficiently plausible indications to conclude that an economic operator has entered into agreements with other economic operators aimed at distorting competition may exclude or may be required by Member States to exclude this operator from participation in a procurement procedure. The article is structured as follows: First the possible consequences of bid rig- ging by cartel members will be discussed from the viewpoint of public procurement law. Next, the aims and effects of self-cleaning policies will be described. The article will then focus on leniency initiatives within the framework of competition law and will conclude by setting off leniency and self-cleaning opportunities to understand their levels of success and to establish whether the recent EU self-cleaning policy will be effective to reduce anticompetitive behaviour.

\section{Exclusion for Reasons of Bid Rigging in Public Procurement}

Bid rigging or collusive tendering is a form of coordination between economic operators that can adversely influence the outcome of a public procurement process. It occurs when firms, that would otherwise be expected to compete, secretly conspire to raise prices, lower the quality of goods or services and/or restrict supply for purchasers who wish to acquire products or services through a bidding process. ${ }^{8}$ Bid rigging in public procurement deprives the public sector of genuine opportunities to achieve value for money and is a major risk to the effectiveness and integrity of public procurement procedures. Bid rigging schemes can take the form of cover bidding where companies purposely and knowingly submit bids that will not be chosen to give the impression of true competition. Companies can also agree to refrain from bidding (bid suppression) or to rotate their bids (bid rotation) so that the previously designated bidder will win the procurement procedure. Finally, bidders can allocate the market and agree not to compete for contracts procured by certain contracting authorities or in certain geographic

\footnotetext{
3 R Majtan, 'The Self-Cleaning Dilemma: Reconciling Competing Objectives of Procurement Processes', 245 The Geo. Wash. Int'l L. Rev., 2013, p. 316.

4 Majtan (n 3), 321.

5 See also Title 18 of the United States Code and the civil False Claims Act.

6 Knowing failure to timely disclose credible evidence of any of the above violations remains a cause for suspension and/or debarment until 3 years after final payment on a contract. See Articles 9.406-2(b)(1)(vi) and 9.407-2(a)(8)) FAR.

7 Majtan (n 3), 320.

8 OECD, Guidelines for Fighting Bid Rigging, 2009, p. 1.
} 
areas. Bid rigging cases represent a significant share of cartel enforcement in many countries. ${ }^{9}$

The ability of undertakings to collude and to form a bid rigging cartel depends partly on market concentration and the degree of rivalry. ${ }^{10}$ Indeed, if industries are concentrated, it is more likely that economic operators meet each other faster which makes it easier to reach a cartel agreement. Furthermore, a small market may lead to higher profits as there is less distribution of income. If industries are very competitive and rivalry is fierce, competitors are more likely to cooperate if they expect a (higher) number of repeated interactions in the future. ${ }^{11}$

The fight against bid rigging has also been an OECD competition enforcement priority since $1998 .^{12}$ As public procurement represents $29 \%$ of general government expenditure and $13 \%$ of GDP in the OECD Members, in 2009 Guidelines were issued for fighting bid rigging in the public procurement context. ${ }^{13}$ These Guidelines aimed to assist Members and Partners to prevent, detect and sanction bid rigging in public procurement. Building on national experience with these Guidelines as well as other tools set up by countries to combat bid rigging, the OECD set up a Recommendation to consolidate good practices. ${ }^{14}$ The Recommendation also encourages Governments to assess their public procurement laws and practices at all levels in order to promote more effective procurement and to reduce the risk of bid rigging in public tenders. An important tool that was identified was the education of procurement officials

9 OECD, Policy Roundtables; Ex officio cartel investigations and the use of screens to detect cartels, 2013, p. 27.

10 Other factors that determine the ability of companies to collude are product differentiation and agreements to reach profit maximisation. See S Weishaar, Cartels, Competition and Public Procurment (Cheltenham: Edward Elgar 2013), 29-30.

11 Weishaar (n 10), 30.

12 OECD, Recommendation of the Council concerning Effective Action against Hard Core Cartels, 1998.

13 OECD, Guidelines for Fighting Bid Rigging in Public Procurement, 2009.

14 OECD, Recommendation of the Council in Fighting Bid Rigging in Public Procurement, 2012.

15 OECD, Fighting Bid Rigging in Public Procurement; Report on implementing the OECD Recommendation, 2016, p. 1.

16 The European Commission and the national competition authorities work together. Settlement procedures and leniency policies can mitigate the consequences for cartel members. These will be discussed in paragraph 4 .

17 A Sánchez-Graells, Public Procurement and the EU Competition Rules (2nd edition, Oxford: Hart Publishing 2015), 298.

18 Case C-470/13 Generali-Providencia [2014] ECLI-2469, [35]. on market structures, behaviour and bidding patterns that may indicate collusion in order to detect and investigate suspicious activities. The 2016 Report on the implementation of the 2012 Recommendation indicates that the Recommendation is widely used and that it has led to very significant cost savings. ${ }^{15}$

In the EU, bid rigging practices can be tackled by fines imposed by national competition authorities or national courts or the European Commission, criminal sanctions imposed at Member State level or private enforcement at national level by victims. ${ }^{16}$ The Court of Justice of the EU can annul decisions of the Commission or alter the amount of the fine.

In the EU legislative framework, the effect of bid rigging in the framework of a procurement procedure is laid down in Article 57(4) (d) of Directive 2014/24/EU. It holds that contracting authorities may exclude or may be required by Member States to exclude from participation in a procurement procedure any economic operator where the contracting authority has sufficiently plausible indications to conclude that the economic operator has entered into agreements with other economic operators aimed at distorting competition. While Article 57 contains some other exclusion grounds relating to distortions of competition, such as the prior involvement of an economic operator in the preparation of a procurement procedure, Article $57(4)(d)$ is specifically relevant in case of bid rigging cartels. As cartels can also be covered by Article 101 TFEU it is important to stress the link between Article 57(4) (d) of the Directive and Article 101 TFEU, specifically as Article 57 only refers to agreements aimed at distorting competition while Article 101 TFEU also prohibits decisions and concerted practices that have as their object or effect the distortion of competition. As held by Sánchez-Graells, in order not to strip Article 101(1) TFEU of its effet utile and to ensure the consistency of the EU system, including the precedence of the Treaty, Article 57(4) (d) of the Directive should be interpreted as covering at least all conduct that would be prohibited under Article 101(1) TFEU. ${ }^{17}$ If certain anti-competitive behaviour would not fall under Article 57(4) (d), it should be verified whether Article 57(4) (c) which contains a discretionary exclusion ground for grave professional misconduct that renders the integrity of an economic operator questionable, is relevant, as this Article should be interpreted widely. ${ }^{18}$ 
While exclusion decisions can be an incentive to deter companies from collusion, ${ }^{19}$ it is also true that exclusion decisions reduce the number of companies that can take part in a procurement procedure which in turn may increase the occurrence of collusion. Indeed, as held above, concentrated industries and small markets may incentivise cartel collaboration. Contracting authorities should therefore be vigilant. To prevent bid rigging cartels they can reduce the number of tenders so that it becomes more interesting for economic operators to compete. By having economic operators only compete on quality aspects, contracting authorities can make it more difficult for economic operators to reach an agreement. Close cooperation between contracting authorities and competition law enforcement agencies and enquiries on market prices may also contribute to the prevention of bid rigging cartels as this could mitigate a lack of information at the buyer's side. ${ }^{20}$

Even though there are in theory sufficient possibilities for contracting authorities to exclude certain undertakings (and national legislation sometimes also allows courts to take exclusion decisions, e.g. in the framework of a criminal procedure), in the EU there is no black list that can be consulted to find out whether an economic operator has engaged in certain untrustworthy behaviour. As there is a lack of data on enforcement decisions, contracting authorities have to rely on the information that is provided to them by the economic operators themselves. Sometimes they may be informed by competitors or others that are aware of certain facts. It even seems that contracting authorities do not often take the decision to exclude an economic operator, even if the conditions that allow them to do so are fulfilled. ${ }^{21} \mathrm{~A}$ reason could be that contracting authorities do not want to take the risk of wrongfully excluding an economic operator. After all, in contrast to competition authorities that are used to take decisions on anticompetitive behaviour of companies, public officials are often not trained to take such decisions as their main purpose is to take good price-quality decisions. All these elements do not contribute to the deterrent effect of exclusion provisions, hence creating incentives for bid rigging and other anti-competitive practices. Even in the US, which appears to have the most developed public procurement debarment regime, it was found that the rules when enforced at State level leave too much space for discretion, and in practice, weak enforcement. ${ }^{22}$ The desire to have as much competition as possible as this may lower prices, increase quality or at least prevents shortage on the market can be an important reason. As held by $\mathrm{Au}-$ riol and Søreide, it is for this reason better not to debar all suppliers involved in a cartel collaboration, ${ }^{23}$ but only the supplier that actually benefited from the collusive agreement in the procurement process where the cartel is detected, and let the other cartel members compete for future public tenders. ${ }^{24}$ This mechanism has exactly the same disincentive effect as the debarment of all the firms but will not impede future procurement. ${ }^{25}$ It has been held that it is also possible to only exclude the ring leader or exclude representatives of the management from professional service. ${ }^{26}$ Directive 2014/24/EU however only allows for the exclusion of economic operators as corporate entities.

\section{Self-Cleaning in Public Procurement Law}

Even though the predecessor of Directive 2014/24/EU, Directive 2004/18/EC, did not specifically foresee the possibility to self-clean, in 2005 the Court of Justice held in Fabricom in relation to an exclusion based on the prior cooperation of an economic operator with a contracting authority, that a blanket exclusion is un-

19 The EU exclusion system is deterrence-based and not punitive in nature as the EU has no criminal competence. Exclusion based on a discretionary exclusion ground may be punitive if the respective national system provides for exclusion as a sanction under criminal law. See also Communication from the Commission to the Council and the European Parliament, Disqualifications arising from criminal convictions in the European Union, COM (2006)0073 final as quoted in S Arrowsmith, $\mathrm{H}$-J Prie $\beta$ and P Friton 2009, p. 484.

20 Weishaar (n 10), 32.

21 An analysis by the OECD on foreign bribery cases concluded between 1999 and 2014 revealed that only two out of a total of 427 foreign bribery cases resulted in an exclusion decision.

22 E Auriol and T Søreide, 'An Economic Analysis of Debarment' (2017) 50 International Review of Law and Economics, 40-41, referring to US Department of Justice, Office of the Inspector General, Audit Division, Audit Report 12-25, Audit of Statutory Suspension and Debarment Activities within the Department of Justice, 2012.

23 To the extent that cartel collaboration is listed among the crimes for which suppliers can be debarred, the common rule is to debar all suppliers involved.

24 Auriol/Søreide (n 22), 57.

25 Auriol/Søreide (n 22), 57.

26 Auriol/Søreide (n 22), 59. 
lawful, as it did not give the bidder the opportunity to prove that, in the circumstances of the case, the experience which it had acquired was not capable of distorting competition. ${ }^{27}$ In Michaniki AE the Court confirmed this finding, indicating that an irrebuttable presumption that led to the exclusion of an entire group of undertakings without allowing such undertakings to demonstrate that the values and objectives of the procurement law are not threatened by their participation in a tender procedure is disproportionate. ${ }^{28}$ Furthermore, in Assitur the Court recognised that a national provision containing an absolute prohibition on simultaneous and competing participation in the same tendering procedure by undertakings linked by a relationship of control or affiliated to one another, is intended to prevent any potential collusion between participants and to safeguard the equal treatment of candidates and the transparency of the procedure. ${ }^{29}$ The Court added however that not allowing participants an opportunity to demonstrate that that relationship did not influence their conduct in the course of that tendering procedure runs counter to the effective application of EU law. ${ }^{30}$ It follows that the burden of proof rests on the shoulders of the economic operators involved.

This is confirmed by Article 57(6) of Directive 2014/24/EU which holds that an economic operator may provide evidence to the effect that measures taken by it are sufficient to demonstrate its reliability despite the existence of a relevant ground for exclusion. An economic operator is in the possibility to

27 Joined Cases C-21/03 and C-34/03 Fabricom [2005] I-1559, [36].

28 Case C-213/07 Michaniki AE [2008] I-09999, [54].

29 Case C-538/07 Assitur [2009] ECR I-04219, [22].

30 Case C-538/07 Assitur [2009] ECR 1-04219, [28].

31 S Arrowsmith, $\mathrm{H}-\mathrm{J}$ Prie $\beta$ and P Friton, 'Self-Cleaning as a Defence to Exclusions for Misconduct - An Emerging Concept in EC Public Procurement Law' (2009) 18 P.P.L.R., 259

32 E Hjelmeng and T Søreide, 'Debarment in Public Procurement: Rationales and Realization' in GM Racca and C Yukins (eds), Integrity and Efficiency in Sustainable Public Contracts (Bruylant 2014), 9. See also AL Wetzel, How companies can 'self-clean' corruption, thanks to EU reforms, 2015, available at <https://www .lexology.com/library/detail.aspx?g=0ba25229-29b4-47f4-a4f4 -305283bf921a> Last accessed on 30 March 2018.

33 Arrowsmith/Prie//Friton, 277: Proportionality must apply to all exclusion decisions, also to the mandatory exclusion decisions. See H-J Prie $\beta$, 'The Rules on Exclusion and Self-Cleaning Under the 2014 Public Procurement Directive' (2014) 3 P.P.L.R.,113; C-213/07 Michaniki [2008] ECR I-9999.

34 Member States enjoy discretion with regard to who will decide whether a certain self-cleaning measure is sufficient. self-clean unless it has been excluded by final judgment from participating in an award procedure during the period of exclusion resulting from that judgement in the Member States where the judgement is effective. The rationale of such self-cleaning measures is the restoration of trust in suppliers who have been considered untrustworthy before. If the evidence provided by the economic operator is considered as sufficient, it cannot be excluded from the procurement procedure. Which self-cleaning measures should be taken depends on the personal situation of the operator involved and the seriousness of the offence, as demonstrated by its duration, recurrence and financial impact and the adequacy of the measures employed by the affected company. ${ }^{31}$ For minor crimes codes of conduct, improved internal compliance systems, whistle-blower channels and training for employees is considered to be effective. For more serious offences which brought substantial gains to firms, the involvement of external actors who monitor the firms' internal and external operations may be considered to be appropriate. For the gravest crimes, the replacement of the whole management on top of other initiatives might be necessary. $^{32}$

The obligation of contracting authorities to accept economic operators that have engaged in self-cleaning measures that these contracting authorities consider to be sufficient to demonstrate reliability is based on the non-punitive and incentive-based nature of the EU exclusion system and relating considerations of fairness as it is assumed that competition is on a level playing field again since these operators are assumed to have restored trustworthiness. ${ }^{33} \mathrm{Al}-$ lowing them back in the game entails an increase in competition which contributes to lower prices. This solution can be problematic however since if operators realise that self-cleaning measures will get them off the hook, there is no real incentive not to engage in dishonest behaviour in the first place. Whether a specific self-cleaning measure will be considered as 'sufficient' is up to the contracting authority or another agency to decide. ${ }^{34}$ The Directive merely indicates that the measures should be adequate for the economic operator to demonstrate its reliability and also at national level Member States have generally not provided for detailed rules in this regard. Economic operators do not have any guarantee beforehand that the measures taken by them are sufficient. Measures that are considered not to be sufficient, 
can give rise to a reduction in the exclusion as a full exclusion would not be in line with the principle of proportionality. ${ }^{35}$ However, accepting self-cleaning measures can weaken the deterrent effect of exclusion: if operators realise that self-cleaning measures will get them off the hook, there is no real incentive not to engage in dishonest behaviour in the first place. ${ }^{36}$ Other problems with self-cleaning relate to its unpredictability. As held above, contracting authorities enjoy a large margin of discretion and are often not experienced enough to make sound decisions about these kind of issues. Furthermore, it is needless to say that practical settlement solutions might be very hard to defend politically when companies have collaborated in a cartel facilitated by corruption. ${ }^{37}$

As Directive 2014/24/EU only needed to be implemented by 18 April 2016 and as the Directive does not contain an obligation for contracting authorities to report or monitor any self-cleaning initiatives, there are currently not many traces of actual selfcleaning statements provided by economic operators in the framework of specific public procurement procedures. Being a well-developed and mature procurement system, the US has a lot of experience with selfcleaning policies. Nevertheless, there is no inherent right to escape debarment if self-cleaning measures are taken. In the US, the voluntary disclosure of wrongful behaviour (self-cleaning) has been considered a reason to possibly (not necessarily) preclude debarment or a mitigating factor for debarment. It turned out however that this possibility did not have sufficient incentive effects as it did not give rise to a significant increase of voluntary disclosure. For this reason there was a need to force economic operators to comply with ethics rules, and debarment was retained as the main deterrence tool. Accordingly, in the US, firms and individuals face the risk of suspension or debarment not only for misconduct itself, but also for the failure to report such misconduct. ${ }^{38}$ For this reason, since 2008 US federal suppliers have been required to establish corporate compliance programmes, self-report any wrongful conduct and exclude wrongdoers or potential wrongdoers from their organisation. ${ }^{39}$

It follows that the incentive-based approach was replaced by a mandatory-based deterrence approach which includes an additional sanction (debarment) for not reporting wrongdoing while requiring contractors to have internal compliance programmes. ${ }^{40}$
It follows that a self-cleaning incentive-based approach without adequate deterrence-based sanctions such as debarment may not sufficiently ensure integrity in public procurement. ${ }^{41}$

As the European Directive guarantees an escape from exclusion, it can at first sight be expected that there will be more applications for self-cleaning than in the US. On the other hand, as indicated above, due to a lack of rules and/or guidelines, economic operators will never know in advance whether they satisfy the burden of proof required from the specific contracting authority. This makes it possible that also in the European Union the voluntary incentivebased self-cleaning theory without adequate deterrence-based sanctions such as debarment will not necessarily increase integrity, specifically as selfcleaning measures require a substantial investment of time and money. ${ }^{42}$ In the framework of EU competition law however, voluntary applications for leniency are very successful. The leniency procedure and the reasons for this success will now be discussed. By comparing the incentives and application of the leniency system in competition law with the self-cleaning procedure in public procurement law, I will try to establish whether the factors of success in competition law are equally applicable in procurement law. In this way I will try to grasp the actual significance of the fairly recent EU self-cleaning policy.

35 Case C-326/88 Hanssen [1990] in which the Court held that whilst the choice of penalties for infringements of Community law remains within the discretion of the Member States, penalties should be effective, proportionate and dissuasive. See with regard to the EU's own Procurement Regulation Article 133a of Council Regulation No 1605/02/EC on the Financial Regulation applicable to the general budget of the European Communities which indicates that the institution responsible should take into account different factors in order to determine the duration of an exclusion and to ensure compliance with the principle of proportionality.

36 S Schoenmaekers, 'The EU Debarment Rules: Legal and Economic Rationale' (2016) 3 P.P.L.R, 98.

37 Auriol/Søreide (n 22), 42.

38 Majtan (n 3), 321.

39 S Williams-Elegbe, Fighting Corruption in Public Procurement - A Comparative Analysis of Disqualification Measures (West Sussex: Hart Publishing 2012), 309.

40 Majtan (n 3), 321.

41 Restitution can be qualified as another deterrence-based sanction As held by Article 57(6), it can be used as part of self-cleaning. If it has a sufficient deterrent impact, it may even replace debarment. However, restoring a status quo might not be a sufficient incentive.

42 Majtan (n 3), 300. 


\section{Leniency Initiatives in the Framework of EU Competition Law}

The European Commission, national courts and the competition authorities of the Member States work in close cooperation in their capacity of public enforcers or review courts. National competition authorities and courts are obliged to apply Articles 101 and 102 TFEU where they apply national competition law to agreements and practices which may affect trade between Member States. Based on Article 23(2) of Regulation 1/2003, ${ }^{43}$ the European Commission can impose fines on undertakings and associations of undertakings where they, either intentionally or negligently, infringe Articles 101 or 102 TFEU, e.g. by the creation of a cartel. When the Commission imposes fines on cartel members that have violated EU competition law, it has a lot of discretion. The basic amount of the fine imposed on undertakings is related to a proportion of the value of sales, depending on the degree of gravity of the infringement, multiplied by the number of years of infringement. $^{44}$

Competition authorities can look for antitrust violations themselves or obtain information from third parties. Furthermore, in its Leniency Notice, ${ }^{45}$ the Commission sets out part of the framework that is used to incentivise cartel members to cooperate with the authorities even if competition rules have been infringed. Undertakings which have been party to secret cartels affecting the European Union get a re-

43 Council Regulation No 1/2003 of 16 December 2002 on the implementation of the rules on competition laid down in Articles 81 and 82 of the Treaty, OJ L 1, 4.1.2003, p. 1-25.

44 Guidelines on the method of setting fines imposed pursuant to Article 23(2)(a) of Regulation No 1/2003, OJ C 210, 1.9.2006, p. $2-5$. As a general rule, the proportion of the value of sales taken into account will be set at a level of up to $30 \%$ of the value of sales. To decide whether the proportion of the value of sales to be considered should be at the lower end or at the higher end of that scale, the Commission will have regard to a number of factors, such as the nature of the infringement, the combined market share of all the undertakings concerned, the geographic scope of the infringement and whether or not the infringement has been implemented (point 22).

45 Commission Notice on Immunity from fines and reduction of fines in cartel cases, also referred to as 'Leniency Notice', OJ C 298, 8.12.2006, p. 17-22.Commission Notice on Immunity from fines and reduction of fines in cartel cases (Text with EEA relevance).

46 Commission Notice ( $\mathrm{n}$ 45), point 11.

47 Commission Notice ( $\mathrm{n} 45$ ), point 12.

48 Commission Notice (n 45), point 13. ward in the form of an elimination or reduction of fines for cooperation in the Commission investigation.

An undertaking being the first to disclose to the Commission its participation in a cartel will obtain immunity from any fine as long as the Commission believes that the information submitted will enable it to carry out a targeted inspection in connection with the alleged cartel (point 8(a) of the Notice) or find an infringement of Article 101 TFEU in connection with the alleged cartel (point 8(b) of the Notice). Immunity regarding the establishment of an infringement of Article 101 TFEU will only be granted if the Commission did not have at the time of the submission, sufficient evidence to find an infringement of Article 101 TFEU in connection with the alleged cartel and that no undertaking had been granted conditional immunity from fines under point 8(a) in connection with the alleged cartel. In order to qualify an undertaking must be the first to provide contemporaneous, incriminating evidence of the alleged cartel as well as a corporate statement which would enable the Commission to find an infringement of Article 101 TFEU. $^{46}$ In addition, the undertaking should cooperate genuinely, fully, on a continuous basis and expeditiously from the time it submits its application throughout the Commission's administrative procedure. It also needs to have ended its involvement in the alleged cartel immediately following its application except if the Commission would consider continuous involvement necessary to preserve the integrity of the inspections. Finally, the undertaking may not have destroyed, falsified or concealed evidence of the alleged cartel nor disclosed the fact or any of the content of its application, except to other competition authorities. ${ }^{47}$ The Notice does not include that applicants should have paid compensation to victims. An undertaking which took steps to coerce other undertaking to join the cartel or to remain in it is not eligible for immunity from fines. $^{48}$

Undertakings that do not meet the conditions for immunity can still obtain a reduction in fines in case they provide the Commission with evidence that represents significant added value by its very nature and/or level of detail with respect to the evidence that is already in the Commission's possession. To obtain a reduction of fines, the same conditions with regard to cooperation with the Commission, ending of cartel membership, use of information and disclosure 
of the application are applicable. ${ }^{49}$ The level of reduction is $30-50 \%$ for the first undertaking to provide signification added value, $20-30 \%$ for the second undertaking and up to $20 \%$ for subsequent firms providing significant added value. ${ }^{50}$ The Commission will take into account the time of reporting and the extent of the information's value. Guidance as to the size of the reduction in absolute terms can be found in the European Commission's Fining Guidelines. ${ }^{51}$ Undertakings that have coerced other undertakings to join or remain in the cartel might still qualify for a reduction of fines.

Even though the detection rate of bid rigging cartels is very low as victims are generally not aware that the bids have been rigged, leniency programmes within the framework of EU competition law have proven to be very successful in fighting cartels. ${ }^{52}$ Most cartels that have recently been detected in the EU were revealed by a cartel member applying for the leniency programme: it concerns $83 \%$ of the cases in $2008,86 \%$ in 2009 and $100 \%$ in 2010 to $2013 .{ }^{53}$

By creating a sphere of distrust or insecurity among its members, the aim of leniency programmes is the destabilisation of the organisation, and ultimately, its detection through confession. ${ }^{54}$ As such, leniency programmes try to push for a change in cartel member's sentiments.

Nevertheless, as held by Wils, the number of leniency applications is not a good indicator of the suc-

49 Commission Notice (n 45), point 24.

50 Commission Notice (n 45), point 26.

51 Guidelines on the method of setting fines imposed pursuant to Article 23(2)(a) of Regulation No 1/2003, OJ C 210, 1.9.2006, p. $2-5$. Fine reductions have been provided on a discretionary basis for leniency applicants that arrive after the start of an investigation. See J Zhou, 'The Dynamics of Leniency Application and the Knock-On Effect of Cartel Enforcement' (2016) 2 Bruegel Working Paper, 15. The undertakings can apply for a reduction of fines under the Settlement Procedure as provided for in Article 10 a of Regulation 773/2004 of 7 April 2004 relating to the conduct of proceedings by the Commission pursuant to Articles 81 and 82 of the EC Treaty, OJ L 123, 27.4.2004, p. 18-24. The opening of such an investigation does not significantly affect the rate of leniency applications in the market investigated as immunity will not be granted.

52 Auriol/Søreide (n 22), 57; S Weishaar, '2014 Procurement Reforms and Bid Rigging: Mixed Blessing or our Happily Ever After?' in S Schoenmaekers, N Philipsen and W Devroe, State aid and Public Procurement in the European Union, (Antwerp: Intersentia 2014), 105.

53 Auriol/Søreide (n 22), 57 referring to C Marvao, 'The EU Leniency Programme and Recidivism' (2014) 48 Review of Industrial Organization, 1-27.

54 N Zingales, 'European and American Leniency Programmes: Two Models Towards Convergence?' (2008) 1 (5) The Competition Law Review, 8-11. cess of a leniency policy as it may reflect excessive generosity and thus a weakening rather than a strengthening of deterrence. ${ }^{55}$ The imposition of more and higher penalties, without an increase in the competition authority's resources, is however a clear sign of success as more and higher penalties entail more deterrence and hence fewer antitrust violations. $^{56}$

As immunity applicants have no incentive to provide for unreliable information given that they risk losing the benefit of immunity if they provide misleading information and given the fact that immunity from punishment is the highest benefit applicants can obtain, ${ }^{57}$ it is clear that leniency programmes are of the utmost importance, specifically as cartels are continuous wrongdoings that involve prohibited behaviour over time. Furthermore, the importance is even stressed more by the fact that when cartels in different markets overlap in membership, leniency applications in one market tend to closely follow the dawn raids in other markets. ${ }^{58}$ This is due to the fact that with cartel profiling, the authority increases the probability of investigation in a second market in which the leniency applicant in the first market also operates. ${ }^{59}$ As antitrust investigations in a market increase leniency applications in related markets, the Commission's leniency programme enhances the EU's detection capabilities. $^{60}$

55 W Wils, 'Leniency in Antitrust Enforcement: Theory and Practice' (2007) 1(30) World Competition: Law and Economics Review, 33.

56 Wils (n 55), 33.

57 Wils (n 55), 45

58 In this regard it is interesting to note that $82 \%$ of the by Zhou sampled colluders engaged in collusion in more than one market. See Zhou (n 51), 14.

59 Zhou (n 51), 12, referring to LM Marx, C Mezzetti and RC Marshall, 'Antitrust Leniency with Multi-Product Colluders' (2015) 7 (3) American Economics Review, 205-240. It should be noted however that if there is not enough deterrence regarding detection in second markets, the same companies might participate in a number of cartels in different markets in the EU and take turns to apply for leniency every time one of the cartels is (about to be) detected by the competition authority, so that the level of expected sanction would be lower. See Zingales (n 54), 41 and Wils (n 55), 45.

60 J Zhou (n 51), 4. In this regard it can be noted that the US Department of Justice can on the basis of the 'Amnesty Plus' programme under which a firm being prosecuted for collusion that has not received leniency can receive reduced penalties if it applies for leniency in a separate market in which it has also engaged in collusion. This however might be an incentive to join at least more than one cartel. Vice versa, under the Penalty Plus, the failure to confess collusion in separate markets can put firms at risk for increased fines should they later be discovered for collusion in those markets. Zingales (n 54), 25, 40. 
Of course this can only hold true if the Commission's antritrust investigations are made public. Interesting to note is that colluders engaged in a market allocation or bid rigging infringement are more likely to apply than colluders not engaged in these infringements. ${ }^{61}$ In any case, it is clear that society will be better off with the operation of a leniency programme since it will get an additional benefit for each collusion that it manages to avoid. ${ }^{62}$

Due to the great success of the Commission's leniency programme, more cartels were uncovered leading to a very high workload for the Commission resulting in backlog of work. For this reason cartels are now often dealt with under the settlement procedure that was introduced in 2004. ${ }^{63}$ Settlements serve to speed up competition cases. After the European Commission has completed a cartel investigation, it can offer a settlement to the participants that acknowledge their liability for the infringement. They can receive a $10 \%$ reduction in fines and avoid costly litigation. Settlements allow the Commission that has the intention to fine, several advantages: it saves legal resources, obtains access to information easily and can fine rather fast. ${ }^{64}$

The importance of leniency programmes for the public enforcement of Union competition law and the importance of the non-disclosure of leniency applications and settlement submissions has been confirmed by Directive 2014/104/EU relating to actions for damages under national law for infringements of national and European competition law provisions. ${ }^{65}$
While the Directive recognises that many decisions of competition authorities in cartel cases are based on a leniency application, and damages actions in cartel cases generally follow on from those decisions so that leniency programmes are important for the effectiveness of actions for damages in cartel cases, it also indicates that undertakings might be deterred from cooperating with competition authorities under leniency programmes and settlement procedures if self-incriminating statements such as leniency statements and settlement submissions, which are produced for the sole purpose of cooperating with the competition authorities, were to be disclosed. ${ }^{66}$ To ensure the continued willingness of undertakings to approach competition authorities voluntarily with leniency statements or settlement submissions, Article 6(6) holds that Member States shall ensure that, for the purpose of actions for damages, national courts cannot at any time order a party or a third party to disclose leniency statements and settlement submissions. It follows that these documents are fully exempted from the disclosure of evidence. ${ }^{67}$ That exemption should also apply to verbatim quotations from leniency statements or settlement submissions included in other documents. ${ }^{68}$ While every individual has the right to claim damages for loss caused to him by conduct that distorts competition and while this rights can even discourage anti-competitive behaviour, ${ }^{69}$ undertakings applying for leniency play a key role in exposing secret cartel infringements and in bringing them to an end, thereby often mitigating
61 J Zhou (n 51), 8.

62 Zingales (n 54), 7.

63 See Article 10a of Commission Regulation 773/2004 as amended by Commission Regulation 622/2008 as regards the conduct of settlement procedures in cartel cases, OJ L 171, 1.7.2008, p. $3-5$

64 Undertakings indicate the fine they are willing to pay, agree to a shorter investigative procedure and waive their right of access to the Commission's file. As also non-cooperating companies can commit to follow the settlement procedure and also subsequent firms can get discounts (leniency applicants get an additional $10 \%$ discount). As settlement submissions will not be disclosed, (the statements of companies can be recorded orally so as to prevent private plaintiffs benefiting from the undertaking's statements), private enforcement initiatives will not automatically follow. Furthermore, companies can also offer commitments to meet the concerns expressed to them by the Commission where the Commission intends to adopt a decision requiring that an infringement of Article 101 or 102 TFEU be brought to an end without having the intention to fine (Article 9 of Regulation $1 / 2003 /$ EC). Such commitments, which can be made binding focus on the company's future behaviour and allow the Commis- sion to save legal resources as it can correct anti-competitive behaviour rather fast. Economic operators can escape a formal commission decision in which a competition law violation that can give rise to private damage action is pronounced.

65 Directive 2014/104/EU of the European Parliament and of the Council of 26 November 2014 on certain rules governing actions for damages under national aw for infringements of the competition law provisions of the Member States and of the European Union, L 349/1.

66 Directive 2014/104/EU, Recital 26.

67 In Pfleiderer, a case that was pronounced before the entry into force of Directive 2014/104/EU, the Court held that National courts should therefore weigh the respective interests in favour of disclosure of the information and in favour of protection of that information provided voluntarily by the applicant for leniency on a case-by-case basis. Case C-360/09 Pfleiderer [2011] ECR I-05161, [30-31]. See also Case C-536/11 Donau Chemie [2013] ECLI-366.

68 Directive 2014/104/EU, Recital 26.

69 Case C-360/09 Pfleiderer [2011] ECR I-0516, [23-28]. See also Case C-753/99 Courage and Crehnan [2001] ECR I-6297. 
the harm which could have been caused had the infringement continued. For this reason the European legislator considers it appropriate to protect undertakings which have received immunity from fines from a competition authority under a leniency programme from undue exposure to damages claims. ${ }^{70}$

\section{Self-Cleaning vs. Leniency: Comparable Approaches in Different Settings?}

The EU's self-cleaning and leniency policies have several similarities. First of all, both policies are voluntary. Economic operators in public procurement procedures are never obliged to self-clean and to admit that they have entered into agreements with other economic operators to escape exclusion. From a leniency perspective under competition law, they are at no time required to report their involvement in a cartel to get immunity or reduction of fines. Secondly, both policies are focused on companies. While Directive 2014/24/EU indicates that only undertakings can be excluded from a procurement procedure and can hence continue to be admitted in a procedure after self-cleaning measures have been taken, the Leniency Notice is focused on the immunity or reduction of fines imposed on undertakings. At EU level, this entails that if a company gets leniency or can self-clean, the individuals are off the hook as there is no criminal prosecution at EU level. Nevertheless at Member States' level prison sentences and personal fines can still be imposed. Thirdly, both leniency and self-cleaning applications have to be done at early stages. While a successful leniency applicant needs to be first to provide contemporaneous, incriminating evidence of the alleged cartel, self-cleaning applications should be submitted before the contracting authority is making a decision on the fulfilment of the selection criteria. Fourthly, while Article 57(6) forbids contracting authorities to exclude economic operators when self-cleaning evidence is considered to be sufficient, the Commission's Leniency Notice obliges the Commission to grant immunity from any fine if the conditions mentioned in this Notice are satisfied. On the other hand both the contracting authorities and the Commission have a considerable amount of discretion to decide whether the evidence that is provided to them is sufficient from their perspective. Of Importance is that the quality of evidence should in both cases be substantial to ensure a certain level of deterrence. The risk that economic operators might get excluded or might get fined anyway even if they came clean, can in theory entail that they are less likely to take such steps. In practice, however, this might not be the case. The 2014 OECD Report on the crime of foreign bribery in which enforcement actions for foreign bribery offences are studied has indicated that the majority of bribes (57\%) are paid to obtain public procurement contracts. $^{71}$ While $31 \%$ of foreign bribery cases were brought to the attention of law enforcement authorities by self-reporting, only two companies were excluded. ${ }^{72}$ Even though bribing officials cannot be
70 Directive 2014/104/EU, Recital 38. In this regard it should be considered that the decision of the competition authority finding the infringement may become final for the immunity recipient before it becomes final for other undertakings which have not received immunity, thus potentially making the immunity recipient the preferential target of litigation. It is therefore held appropriate that the immunity recipient be relieved in principle from joint and several liability for the entire harm and that any contribution it must make vis-à-vis co-infringers does not exceed the amount of harm caused to its own direct or indirect purchasers or in the case of a buying cartel, its direct or indirect providers. To the extent that a cartel has caused harm to those other than the customers or providers of the infringers, the contribution of the immunity recipient should not exceed its relative responsibility for the harm caused by the cartel. That share should be determined in accordance with the same rules used to determine the contributions between infringers. The immunity recipient should remain fully liable to the injured parties other than its direct or indirect purchasers or providers only where they are unable to obtain full compensation from the other infringers. See Article 11(5) and Recital 38 of Directive 2014/104/EU. Furthermore, Article 11(5) on joint and several liabilities indicates that Member States shall ensure that an infringer may recover a contribu- tion from any other infringer, the amount of which shall be determined in the light of their relative responsibility for the harm caused by the infringement of competition law. The amount of contribution of an infringer which has been granted immunity from fines under a leniency programme shall not exceed the amount of the harm it caused to its own direct or indirect purchasers or providers

71 See OECD Foreign Bribery Report, 2014, p. 19 available at <http://www.ethicalsystems.org/sites/default/files/files/OECD $\% 20 F$ Freign \%20Bribery\%20Report.pdf $>$ (last accessed on 30 March 2018). Foreign bribery is defined as offering, promising or giving any undue pecuniary or other advantage, whether directly or through intermediaries, to a foreign public official, for that official or for a third party, in order that the official act or refrain from acting in relation to the performance of official duties, in order to obtain or retain business or other improper advantage in the conduct of international business.

72 It should be noted however that the $31 \%$ could in theory be self reporting outside a procurement context. The number 31 relates to all self-reporting. It should also be noted that since 2008 there is a mandatory system of self-reporting for federal procurement in the US. 
equalised with anti-competitive behaviour due to cartel formations, it seems that exclusion may lose its meaning due to self-reporting. ${ }^{73}$ This is even more striking as the vast majority of EU Member States are member to the OECD Anti-Bribery Convention and the cases studied dated from 1999 until 2014, hence even before Directive 2014/24/EU by which self-cleaning became a visible possibility in the EU, was promulgated.

Looking at the most crucial differences between both policies, it should be noted first that a key factor regarding cartels is the involvement of more than one culpable party in the scene. As held by Zingales, the leniency mechanism would not make sense for personal crimes as if one knows that he will be able to surrender himself to the authorities in order to avoid detection, then he will not be deterred in the first place because he will be aware of the possibility to get around the rule of law which prohibits the conduct. $^{74}$ This specifically identifies a sensitive issue when it comes to exclusion in public procurement law where economic operators might feel that they can do anything as long as they show regret and adopt some measures afterwards. The fact that more parties are involved when it comes to leniency is also highlighted by the fact that in cartel cases, applicants for leniency are often afraid for retaliation by the other cartel members. A second difference between both policies is the identity of the decisiontaker: decisions on leniency are taken by specialised national competition authorities or the European Commission, while decisions on self-cleaning rest with each individual contracting authority whose personnel is often only trained to take price-quality decisions and not on ethical issues. In this regard it should be noted that if a contracting authority wants to base its exclusion decision on the basis of an infringement that was identified by a national competition authority, a problem can be that such identifi-

\footnotetext{
73 Auriol/Søreide (n 22); Hjelmeng/Søreide (n 32), 7.

74 Zingales (n 54), 7.

75 This is only different if the period of exclusion has been set by final judgement.

76 Leniency Notice, Point 12.

77 Leniency Notice, Point 12(b). This is only different if in the Commissions view, continued cartel membership would be reasonably necessary to preserve the integrity of the inspections.

78 Auriol/Søreide (n 22), 57.
}

cation by a competition authority and thus also a decision on leniency which can be relevant in the light of self-cleaning as it demonstrates an operator's willingness to cooperate, might not be available within three years from the date of the relevant event. Article 57(7) of Directive 2014/24/EU prescribes however that where the contracting authority has sufficiently plausible indications to conclude that the economic operator has entered into agreements with other economic operators aimed at distorting competition, the maximum period of exclusion - if no sufficient self-cleaning measures are taken by the economic operator to demonstrate its reliability cannot exceed three years from the date of the relevant event. ${ }^{75}$ Finally, leniency will in principle be granted for the mere fact of being the first disclosing and demonstrating participation in a cartel together with a corporate statement and genuine cooperation with the Commission, regardless of any compensatory measures that have been taken by the applicant. ${ }^{76}$ Self-cleaning on the other hand requires more: to demonstrate its reliability the economic operator has to prove that it has paid or has undertaken to pay compensation in respect of any damage caused by its offence or misconduct, clarified the facts and circumstances in a comprehensive manner by actively collaborating with the investigating authorities and taken concrete technical, organisational and personnel measures that are appropriate to prevent further criminal offences or misconduct. For leniency, concrete actions are not required as the undertaking should merely have ended its involvement in the alleged cartel immediately following its application. $^{77}$

When competition law and public procurement law are looked at together, the risk that economic operators might get excluded from a procurement procedure anyway, can make it less likely that they will apply for leniency under competition law. It follows that exclusion of firms for their involvement in cartel collaboration in public procurement can undermine the efficiency of the leniency programmes established by competition authorities. ${ }^{78}$ Indeed, even though competition authorities in the EU can grant total immunity or a reduction of fines, they are not competent to grant leniency for exclusion within the framework of a public procurement procedure. It has therefore been suggested that the firm coming forward to report the illegal activity of bid rigging should be excluded from the mechanism of debar- 
ment. ${ }^{79}$ However as leniency programmes serve different goals than self-cleaning policies, I do not think that this should be the case. With its leniency programme the European Commission aims to reward companies for their cooperation and protects the market. As held above self-cleaning policies serve these goals as well but require in addition the protection of the victim by damage compensation. In any case, there is no reason why economic operators would not apply for leniency under competition law and self-cleaning under public procurement law at the same time, while keeping a close eye on whether the principles of equal treatment and proportionality are respected by contracting authorities. These principles, together with a positive reaction to a leniency application, can contribute to support an operators' application for self-cleaning as a grant of leniency by the Commission or national competition authorities indicates that the company is at least cooperative.

The question can now be asked whether the abovementioned differences and similarities between leniency and self-cleaning can allow us to anticipate the level of success of self-cleaning in the EU. As indicated before, while the Court has stated on several occasions that economic operators should have the opportunity to prove that they did not engage in anti-competitive behavior, Directive 2014/24/EU codified this principle in legislation, contributing to the awareness of contracting authorities and economic operators. For this reason it is expected that applications for self-cleaning will increase. As leniency applications in the EU are high in number ${ }^{80}$ and as self-cleaning and leniency policies have several similarities, one might assume that the EU's selfcleaning system, as implemented by Member States, will be successful as well. This is even more so as there does not need to be more than one culpable party to be able to successfully self-clean. In general, economic operators do not need to fear for retaliation by other parties on the market. This might be different however in case one admits to be part of a cartel as contracting authorities will know for (future) contracts which other parties represent a risk and there will always be the risk that this information is communicated to competition authorities. If the contracting authority is not trustworthy itself, the rules of the game are different of course as it might then only be interested in fast financial gains, perhaps even open to bribes. On the other hand, if one is the only party involved, there is less risk of being caught, so that the incentive to come clean is lower if the anti-competitive conduct is not yet discovered. Furthermore, the fact that self-cleaning requires more than leniency (damage compensation, concrete technical, organisation and personnel measures) might also be a disincentive for companies to publicly acknowledge their wrongdoing. In addition, while Directive 2014/104/EU on actions for damages under national law for infringements of EU competition law specifically mentions that leniency statements should be exempted from the disclosure of evidence, there is no such guarantee in the procurement Directive which strongly embraces the transparency principle. While Article 55 of Directive 2014/24/EU concerns the personal notification of candidates or tenderers of decisions regarding their personal tender submission, Article 84 indicates that for every contract, contracting authorities have to draw up a written report including the reasons for selection or rejection of a tenderer. This report, or its main elements, has to be communicated to the Commission or the competent authorities, bodies or structures referred to in Article 83, where they so request. It follows that the procurement Directive does not contain a guarantee that certain information that was provided for reasons of self-cleaning is kept confidential, making economic operators more fragile to prosecution by competition authorities or damages actions by private actors. Of course, as Article 83 only indicates that such report will be communicated upon request, this will only occur if such request has actually been made. Without pretending

79 PA Giosa, 'Debarment and Leniency Programme: Can two birds be killed with one stone?', presentation at the Early Career Researcher Event, London, 3 March 2016, available at <https:// pedro-telles-cjkc.squarespace.com/s/Penelope-Giosa-Debarment -and-leniency-PP-ECR-Conference.pptx $+\& c d=2 \& h l=e n \& c t=c l n k$ $\& g l=b e>$ (last accessed on 30 March 2018). In this regard it can be noted that under the old Slovakian public procurement law that was in force prior to the adoption of Directive 2014/24/EU, undertaking who successfully qualified for the leniency programme (immunity as well as fine reduction) were not excluded from participation in public procurement procedures. See $\mathrm{O}$ Blažo, Proportionality and Subsidiarity of European Law and Issues of "Over-Regulation" and "Under-Regulation", paper presented at the International Academic Conference Bratislava Legal Forum, 2015, p. 1494.

80 It should be noted that the US antitrust enforcement system which is based on criminal law, with financial and custodial penalties against individuals seems to be substantially more effective as by also taking into account personal interests, it includes a powerful incentive to confess: avoiding custodial sanctions. This is only possible for individuals who come forward before any investigation has started. See Zingales (n 54), 12. 
to be complete, it seems that there are, at least after a first theoretical analysis, that there are less incentives for self-cleaning than for leniency applications in the EU. As Directive 2014/24/EU only had to be implemented by 18 April 2016, it will have to be awaited whether this will also be the case in practice.

Important to note is that experience in the US and at the World Bank seems to confirm this conclusion. As indicated above, firms or individuals in the United States participating in a federal defence procurement procedure could reduce the risk or even completely avoid debarment if they voluntarily disclosed their wrongdoing through a formal programme. While this programme was not an amnesty programme, no contractor participating in it was ever suspended or debarred. ${ }^{81}$ Nevertheless, this did not result in a significant increase in reporting. The Voluntary Settlement Programme of the World Bank, which is still in use and which allows firms and individuals to avoid debarment if they voluntarily disclose their wrongdoing, has also not been used a lot. For this reason the US has supplemented its incentive-based self-cleaning theory with a deterrencebased sanctions. ${ }^{82}$ Accordingly, in the US, firms and individuals face the risk of suspension or debarment not only for misconduct itself, but also for the failure to report such misconduct so that there is an additional sanction (debarment) for not reporting wrongdoing as such. In this light, contractors are required to have internal compliance programmes. ${ }^{83}$ In a way, this deterrence based sanction in US procurement resembles the US Penalty Plus policy in competition law by which the failure to confess collusion in separate markets can put firms at risk for increased fines should they later be discovered for collusion in those markets. Interesting to note in this regard is that Article 23(1) of Regulation 1/2003, the Commission can also impose fines if companies do not cooperate or supply incorrect or misleading in-

1 Majtan (n 3), 317.

82 Majtan (n 3), 300.

83 Majtan (n 3), 321.

84 Article 106(13) of Regulation 2015/1929 of the European Parliament and of the Council of 28 October 2015 amending Regulation No $966 / 2012$ on the financial rules applicable to the general budget of the Union, OJ L 286, 30.10.2015, p. 1-29.

85 Article 106(16) of Regulation 2015/1929. The publication is subject to the decision of the contracting authority. formation. Whether the inclusion of such compliance requirements will also be the destiny of the EU's self-cleaning policy remains to be awaited. As held above, there are several elements that point to this direction. On the other hand, the 2014 OECD Report which dealt with foreign bribery revealed that almost one third of foreign bribery cases were brought to the attention of law enforcement authorities by selfreporting while more than half of foreign bribery crimes took place in the area of public procurement. Even though this report deals with self-reporting for foreign bribery in general and not only in a (cartel-) procurement setting so that its relevance for the current analysis might be insignificant, the fact that selfreporting became mandatory in the US in 2008 might have had a positive impact on the reporting percentage.

\section{The Internal Market Information System}

As indicated above, decisions on self-cleaning in the EU rest with contracting authorities whose officials are often not trained to focus on integrity issues remains problematic. It is therefore recommended that special units are created to deal with such issues or that public officials at least get professional training so that they are not only equipped to balance value versus money but also good versus bad. The decisions taken by these officials should then be registered at EU level, just like decisions taken in the framework of procurement by the EU institutions. Not only can economic operators get a financial penalty in case they try to obtain access to Union funds by participating or requesting to participate in a procurement procedure while being, without having declared it, in a certain exclusion situations, ${ }^{84}$ the Commission will also publish information related to the exclusion and/or financial penalty on its website to reinforce the deterrent effect of the contracting authority's decision. ${ }^{85}$ This allows the European institutions to be better informed when evaluating a candidate for tender. Of course the creation of a register including all decisions taken by national contracting authorities relating to exclusion and self-cleaning issues is more complex than a register including decisions taken by EU institutions as there are countless national or sub-national contracting authorities and the required expertise is often lack- 
ing. The fact that Directive 2014/24/EU does not prescribe the creation of such register nor the communication between contracting authorities of exclusion or self-cleaning decisions is regretful. This is specifically the case as Article 32 of Directive 2006/123/EC ${ }^{86}$ on Services in the Internal Market which is much older already indicates that where a Member State becomes aware of serious specific acts or circumstances relating to a service activity that could cause serious damage to the health or safety of persons or to the environment in its territory or in the territory of other Member States, it is obliged to inform the Member State of establishment, the other Member States concerned and the Commission within the shortest possible period of time. This is also called the Alert Mechanism. ${ }^{87}$ Directive 2013/55/EU amending Directive 2005/36/EC on the recognition of professional qualifications which aims to ensure a high level of consumer protection contains an alert-mechanism based on administrative cooperation as well. While Directive 2005/36/EC already provided for detailed obligations for Member States to exchange information, the 2013 Directive specifies that Member States should not only react to requests for information but that their competent authorities have to be empowered to proactively alert the competent authorities of other Member States about professionals who are no longer entitled to practise their profession. ${ }^{88}$ Such alert has to contain any available details of the definite or indefinite period to which the restriction or prohibition applies and has to be activated through the Internal Market Information (IMI) system, which is is an ITbased information network that links up national, regional and local authorities across borders. ${ }^{89}$ While the system is set up to protect consumers and patients, Article 56a of the amended Directive 2005/36/EC and the Commission Implementing Regulation also provide safeguards for professionals against whom an alert has been issued. These safeguards mainly relate to data protection and to the professionals' right of appeal against a potential wrongful issuance of an alert. ${ }^{90}$ In case of false alerts, professionals should be able to access remedies in the event that any damage has been caused. Experience with IMI has demonstrated that the alert mechanism enables the competent authorities of the Member States to communicate quickly and easily with their counterparts abroad..$^{91}$ Indeed, contracting authorities have the obligation to issue an alert by way of the IMI system within three days after which a decision restricting access to professional activities was adopted. ${ }^{92}$ They have a similar obligation to inform other Member State competent authorities of the expiration of a prohibition or restriction 'without delay'. ${ }^{93}$

While the use of the IMI system is mandatory in the field of professional qualifications, Directive 2014/24/EU only refers to IMI as a useful electronic means to facilitate and enhance administrative cooperation managing the exchange of information on the basis of simple and unified procedures overcoming language barriers. ${ }^{94}$ The use of IMI for public procurement was launched on 20 April 2015 as a pilot project in conformity with Article 86(3) of the Directive. ${ }^{95}$ To the knowledge of the author there is so far hardly any specific information available on the use of the IMI system in the area of procurement. As the use of the system is not mandatory, ${ }^{96}$ it is hard to get an actual view on the added value of the system. Of course, it goes without saying that information on exclusion and self-cleaning has to be easily available among contracting authorities to safeguard value for money and efficiency in public procurement.

86 Directive 2006/123/EC of the European Parliament and of the Council of 12 December 2006 on services in the internal market, OJ L 376, 27.12.2006, p. 36-68.

87 Article 32(2) of Directive 2006/123/EU indicates that the Commission shall promote and take part in the operation of a European network of Member States' authorities in this regard.

88 Recital 29 of Directive 2013/55/EU of the European Parliament and of the Council of 20 November 2013 amending Directive 2005/36/EC on the recognition of professional qualifications and Regulation No 1024/2012 on administrative cooperation through the Internal Market Information System ( 'the IMI Regulation' ), OJ L 354, 28.12.2013, p. 132-170.

89 The alert mechanism has to be used regardless of whether the professional has exercised any of the rights under Directive 2005/36/EC or has applied for recognition of his professional qualifications through the issuance of a European Professional Card or through any other method provided for by that Directive.

90 Commission Implementing Regulation (EU) 2015/983 of 24 June 2015 on the procedure for issuance of the European Professional Card and the application of the alert mechanism pursuant to Directive 2005/36/EC of the European Parliament and of the Council, OJ L 159, 25.6.2015, p. 27-42.

91 Article 56a(2) of Professional Qualifications Directive.

92 Article 56a(2) of Professional Qualifications Directive.

93 Article 56a(5) of Professional Qualifications Directive.

94 Directive 2014/24/EU, Recital 129.

95 Of course the alert procedure has to comply with Union law on the protection of personal data and fundamental rights.

96 Except with regard to professional qualifications as meant in Directive 2005/36/EC. 


\section{Conclusion}

Whether voluntary self-cleaning initiatives within the framework of an EU public procurement procedure will be an effective tool to increase integrity in public procurement remains to be seen. This article argues that there seem to be less incentives for selfcleaning than for leniency applications in the EU legal system. Whether this will be confirmed by practice has to be awaited. As decisions on exclusion and self-cleaning are taken by contracting authorities

97 The IMI system or at least another system (in case experience with the IMI system would not seem to be positive in the field of procurement) by which information is shared should be made mandatory. which often lack the necessary expertise to take decisions that are not related to technical and financial aspects and which are generally not aware about companies' past behaviour, increased professional training and/or the creation of special units dealing with such issues is vital. What is even more important is the creation of a register containing an overview of the exclusion and self-cleaning decisions taken by all contracting authorities. The Procurement Directives should make the application of the IMI system mandatory ${ }^{97}$ just as this is the case regarding the Professional Qualifications Directive. Anyhow, positive decisions upon self-cleaning or leniency applications will always raise the following concern: Will the trustworthy or rather the sly foxes be rewarded? 